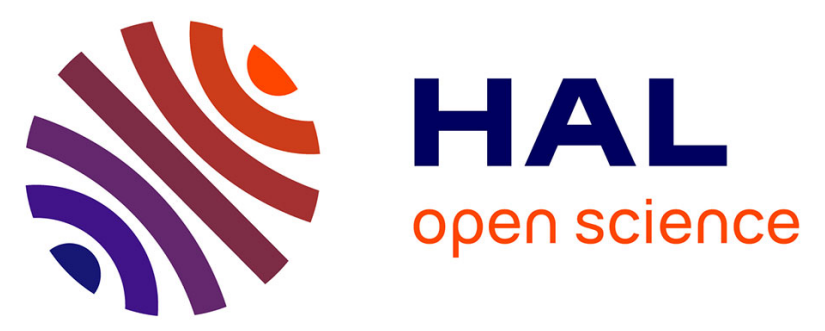

\title{
Sequential fatty acid analysis of a peat core covering the last two millennia (Tritrivakely lake, Madagascar): Diagenesis appraisal and consequences for palaeoenvironmental reconstruction.
}

\author{
Jean-Robert Disnar, Maya Stefanova, Sonia Bourdon, Fatima
}

Laggoun-Défarge

\section{To cite this version:}

Jean-Robert Disnar, Maya Stefanova, Sonia Bourdon, Fatima Laggoun-Défarge. Sequential fatty acid analysis of a peat core covering the last two millennia (Tritrivakely lake, Madagascar): Diagenesis appraisal and consequences for palaeoenvironmental reconstruction.. Organic Geochemistry, 2005, 36, pp.10, 1391-1404. 10.1016/j.orggeochem.2005.06.004 . hal-00023405

\section{HAL Id: hal-00023405 \\ https://hal-insu.archives-ouvertes.fr/hal-00023405}

Submitted on 23 May 2006

HAL is a multi-disciplinary open access archive for the deposit and dissemination of scientific research documents, whether they are published or not. The documents may come from teaching and research institutions in France or abroad, or from public or private research centers.
L'archive ouverte pluridisciplinaire HAL, est destinée au dépôt et à la diffusion de documents scientifiques de niveau recherche, publiés ou non, émanant des établissements d'enseignement et de recherche français ou étrangers, des laboratoires publics ou privés. 


\title{
Sequential fatty acid analysis of a peat core covering the last two millennia (Tritrivakely lake, Madagascar): Diagenesis appraisal and consequences for palaeoenvironmental reconstruction
}

\author{
Jean-Robert Disnar, Maya Stefanovaํㅡ, Sonia Bourdon and Fatima Laggoun- \\ Défarge
}

ISTO, UMR CNRS 6113, bâtiment Géosciences, Université d'Orléans, BP 6759, 45067 Orléans Cedex 2, France

\section{Abstract}

Seven samples from a $1 \mathrm{~m}$ long peat core, taken from the centre of the Tritrivakely maar lake (Madagascar) and covering the last $2300 \mathrm{yr}$, were analysed for their fatty acid (FA) content. Solvent extraction, followed by acid hydrolysis and saponification allowed successive release of "free", $\mathrm{H}^{+}$-labile and $\mathrm{OH}^{-}$-labile bound FAs. Downcore variations in the concentration of individual compounds released by the different treatments allowed distinction between the following three major types of input: (i) primary production; (ii) secondary production (that most certainly forms as a result of microbial degradation of primary products) immediately underlying the sub-surface; (iii) a notable bacterial stock that appears later and slowly at depth. The latter input is revealed by the regularly increasing concentration of several $\mathrm{H}^{+}$-labile compounds with depth. Sedimentary horizons that were sites for good preservation conditions are indicated by high relative amounts of nearly all the compounds, especially those inherited from the primary as well as from the secondary producers (including the primary consumers). In contrast, depth intervals that have been the site for intensive diagenetic alteration contain few compounds, including those inherited from late consumers.

\section{Introduction}

Among the most common families of biochemical constituents, lipids and especially fatty acids (FAs) have the advantage of comprising a highly diversified group of structures (carbon backbone plus possible functional groups) and a notable resistance to degradation. Consequently, these compounds are frequently analysed in order to gain information on organic matter (OM) sources and diagenetic transformations in a diversity of sediments, mainly from recent marine and lacustrine environments (Volkman et al., 2000, Zegouagh et al., 2000 and Garcette-Lepecq et al., 2004). In this respect, despite the fact that they appear advantageous targets because of their dominant or even exclusive OM content, peat deposits have received relatively little attention (Lehtonen and Ketola, 1990 and Lehtonen and Ketola, 1993). Nevertheless, recent studies on lipid biomarkers in peat have been performed with the aim of reconstructing variations in higher plant inputs as well of deriving new climatic change proxies (Dehmer, 1993, Farrimond and Flanagan, 1995, Ficken et al., 1998, Nott et al., 2000, Duan and Ma, 2001, Pancost et al., 2002, Pancost et al., 2003 and Xie et al., 2004). 
When studying FAs organic geochemists classically paid attention either to the "free" fraction or to "bound" compounds commonly released by saponication, without any decisive argument to justify their choice of one or other fraction. It is now well established that more detailed information can be obtained by a study of the various pools of FAs that can be released successively by different chemical treatments (Barnes and Barnes, 1978, Albaigés et al., 1984, Nishimura and Baker, 1987, Amblès et al., 1987, Zegouagh et al., 1996 and Stefanova and Disnar, 2000). Among the "new" treatments, acid hydrolysis has been recognised as being capable of specifically releasing bacterial FAs initially linked to other cell constituents through amide bonds (Rietschel et al., 1972, Mendoza et al., 1987a, Mendoza et al., 1987b, Goossens et al., 1989a and Goossens et al., 1989b). In this paper, we present the results of a three step FA sequential extraction approach carried out on seven samples taken from a one metre peat core representing the uppermost part of the sedimentary fill of the Tritrivakely maar lake in Madagascar. This sequence, which constitutes a ca. $2300 \mathrm{yr}$ long sedimentary record, has previously been the object of a detailed petrographical and geochemical study that allowed distinction of two main accumulation stages during the time in question, the transition from one to the other being most probably driven by a notable regional climate change (Laggoun-Défarge et al., 1999, Bourdon, 1999, Bourdon et al., 1997 and Bourdon et al., 2000). The present work was undertaken to obtain supplementary information on OM inputs and diagenesis through FA analysis. To this end, we applied a new strategy based on sequential FA analysis and comparison of individual component concentration vs. depth.

\section{Materials and methods}

\subsection{Setting and sampling}

The site and sedimentary section have been described by Bourdon et al. (2000). Tritrivakely Lake $\left(19^{\circ} 47 \mathrm{~min} \mathrm{S,} 46^{\circ} 55 \mathrm{~min} \mathrm{E}, 1778 \mathrm{~m}\right.$ ) is located in the central part of the volcanic Ankaratra Plateau (Madagascar). It is presently a maar about $600 \mathrm{~m}$ wide and $50 \mathrm{~m}$ deep. As revealed by piston core examination, sedimentary infill represents a more than $40 \mathrm{~m}$ thick accumulation of lacustrine and paludal sediments that probably record the last climatic cycle (Gasse et al., 1994, Sifeddine et al., 1995 and Gasse and Van Campo, 1998). The uppermost $3 \mathrm{~m}$ of sediment consist of peat accumulated during the late Holocene (Burney, 1987 and Gasse et al., 1994).

The regional climate, controlled by latitude and topography, is of the mountain tropical type (mean annual precipitation about $1600 \mathrm{~mm} / \mathrm{yr}$; mean annual temperature about $16{ }^{\circ} \mathrm{C}$ ) with a warm and wet summer and a dry and cool winter (Chaperon et al., 1993). The lake has no surface outlet. Changes in water level are, therefore, directly controlled by the precipitation/evaporation ratio, with considerable variation (e.g., the lake was almost dry in Nov. 1992, while the maximum water level reached $0.6 \mathrm{~m}$ in Jan. 1992 and up to $2 \mathrm{~m}$ after an extremely rainy season in May 1994). The water is fresh, oligotrophic (conductivity about $20.6 \mu \mathrm{S} \mathrm{cm}^{-1}$ ), slightly acidic $(\mathrm{pH} 5.5-$ 6.3) and has a ${ }^{14} \mathrm{C}$ activity of $98.14 \%$, corresponding to an apparent age of about $1000 \mathrm{yr}$ (Gasse et al., 1994). The water body is presently colonised by aquatic and emergent plants. The flora consists of Cyperaceae (Cyperus madagariensis dominant, and Cyperus papyrus and Heliocharis equisetina) with some Poaceae species like Leersia hexandra. Rice and corn are cropped on the slopes of the crater. 
The present study is concerned with the uppermost metre of peat which has accumulated since $2300 \mathrm{yr}$ BP in the maar (Bourdon et al., 1997). The core was taken in 1994 near the centre of the marsh. The sections analysed $(1-4 \mathrm{~cm}$ thick) were taken at $0-1,2-5,9-12,19-22,30-34,59-60$ and $96-99 \mathrm{~cm}$ depth. $\mathrm{C}$ and $\mathrm{N}$ determination was performed using combustion with a Leco ${ }^{\circledR}$ CNS 2000 analyser on an aliquot of the crushed and dried samples.

\subsection{Sequential lipid extraction}

Sequential lipid extraction was performed according to the protocol applied by Stefanova and Disnar (2000). Briefly, a "reversed" sequential extraction scheme was applied, where acid attack preceeded saponification.

\subsubsection{Isolation of "free" extractable lipids}

The lyophilised samples (1-2 g) were soaked overnight in acetone-pentane (1:1), with a 1:50 w/v sample:solvent ratio. The mixture was sonicated $(2 \times 5 \mathrm{~min})$ at ambient temperature. The extracts were separated by filtration and the residues were carefully washed with acetone-pentane. The extract and the washes were combined and the solvent was removed under vacuum.

\subsubsection{Isolation of $\mathrm{H}^{+}$-labile lipids}

The solid residues from the previous step were transferred to $25 \mathrm{ml}$ Pyrex ${ }^{\circledR}$ tubes. Methanol $(10 \mathrm{ml})$ and $3 \mathrm{~N} \mathrm{HCl}(10 \mathrm{ml})$ were added. The tubes were tightly closed under vacuum and left overnight in an oven at $80 \pm 2{ }^{\circ} \mathrm{C}$.

The insoluble residues were isolated by filtration and washed with distilled water. The filtrates were combined, concentrated under reduced pressure to about $10 \mathrm{ml}$ and extracted with diethyl ether $(2 \times 20 \mathrm{ml})$. The soluble portions were dried with anhydrous $\mathrm{Na}_{2} \mathrm{SO}_{4}$, filtered and finally concentrated for chromatographic separation.

\subsubsection{Isolation of $\mathrm{OH}^{-}$-labile lipids}

The solid residues from the previous treatment were transferred to Pyrex ${ }^{\circledR}$ tubes and were saponified with $1.5 \mathrm{~N} \mathrm{NaOH}$. After addition of the $\mathrm{NaOH}$ solution, the tubes were shaken vigorously, closed and left for $48 \mathrm{~h}$ in an oven at $55^{\circ} \mathrm{C}$. After cooling, the reaction products were neutralised with dilute $\mathrm{HCl}$. The insoluble residue was separated using filtration and washed with water and diethyl ether. The organic phase was separated from the aqueous solution. The latter was extracted with diethyl ether until extracts were colourless. Then, the organic phases were combined, dried and concentrated under reduced pressure.

\subsubsection{Fatty acid analysis}

All the lipid extracts were separated into neutral and acidic portions using column chromatography on $\mathrm{KOH}$-impregnated silica gel columns (McCarthy and Duthie, 1962). The acidic fractions, eluted by diethyl ether-HCOOH $(9: 1, \mathrm{v} / \mathrm{v})$ were concentrated and esterified with diazomethane (Lombardi, 1990). Tetradecene 
(cis + trans) was added as an internal standard prior to gas chromatography (GC) and combined gas chromatography-mass spectrometry (GC-MS).

The methylated fractions were analysed using a Perkin-Elmer XL Autosystem ${ }^{\circledR}$ gas chromatograph equipped with a CP sil 5 CB column $(0.22 \mathrm{~mm} \times 30 \mathrm{~m} ; 0.25 \mu \mathrm{m}$ film thickness), a flame ionisation detector $\left(300^{\circ} \mathrm{C}\right)$ and a split/splitless capillary injector maintained at $300{ }^{\circ} \mathrm{C}$ and used in the splitless mode (valve reopened one min after injection). After $1 \mathrm{~min}$ hold at $50^{\circ} \mathrm{C}$, the oven temperature was increased from 50 to $120^{\circ} \mathrm{C}$ at $30^{\circ} \mathrm{C} / \mathrm{min}$ and then from $120^{\circ}$ to $300^{\circ}$ at $5^{\circ} / \mathrm{min}$; this final temperature was maintained for a period of $1 \mathrm{~h}$. The carrier gas was helium.

GC-MS analysis was performed with a Varian 300 chromatograph connected to an Ion Trap ITD 800 (Finnigan Mat) by a $2 \mathrm{~m}$ capillary interface heated to $300{ }^{\circ} \mathrm{C}$. Other GC conditions were identical to those described above. Operating conditions for the ion trap were: temperature, $220^{\circ} \mathrm{C}$; ionisation energy, $80 \mathrm{eV} ; 1 \mathrm{scan} / 2 \mathrm{~s}$ from 50 to 500 amu.

\section{Results and discussion}

\subsection{Bulk composition of samples and acid fractions}

The total organic carbon (TOC), between $43.1 \%$ and $49.6 \%$ over the whole section, expresses a paucity of mineral matter. More important variations affect the $\mathrm{N}$ content, since the $\mathrm{C} / \mathrm{N}$ ratio value reaching 19.6 in the upper level, remains between 12 and 15 below this. The three FA fractions were named as follows: "free", for directly solvent-extracted fractions; " $\mathrm{H}^{+}$-labile" and " $\mathrm{OH}^{-}$-labile" for the fractions released after acid treatment and saponification, respectively. A general description of the FA distributions in the different fractions is given in Table 1. The changes in total FA content with depth in the three fractions are shown in Fig. 1. These profiles are further discussed.

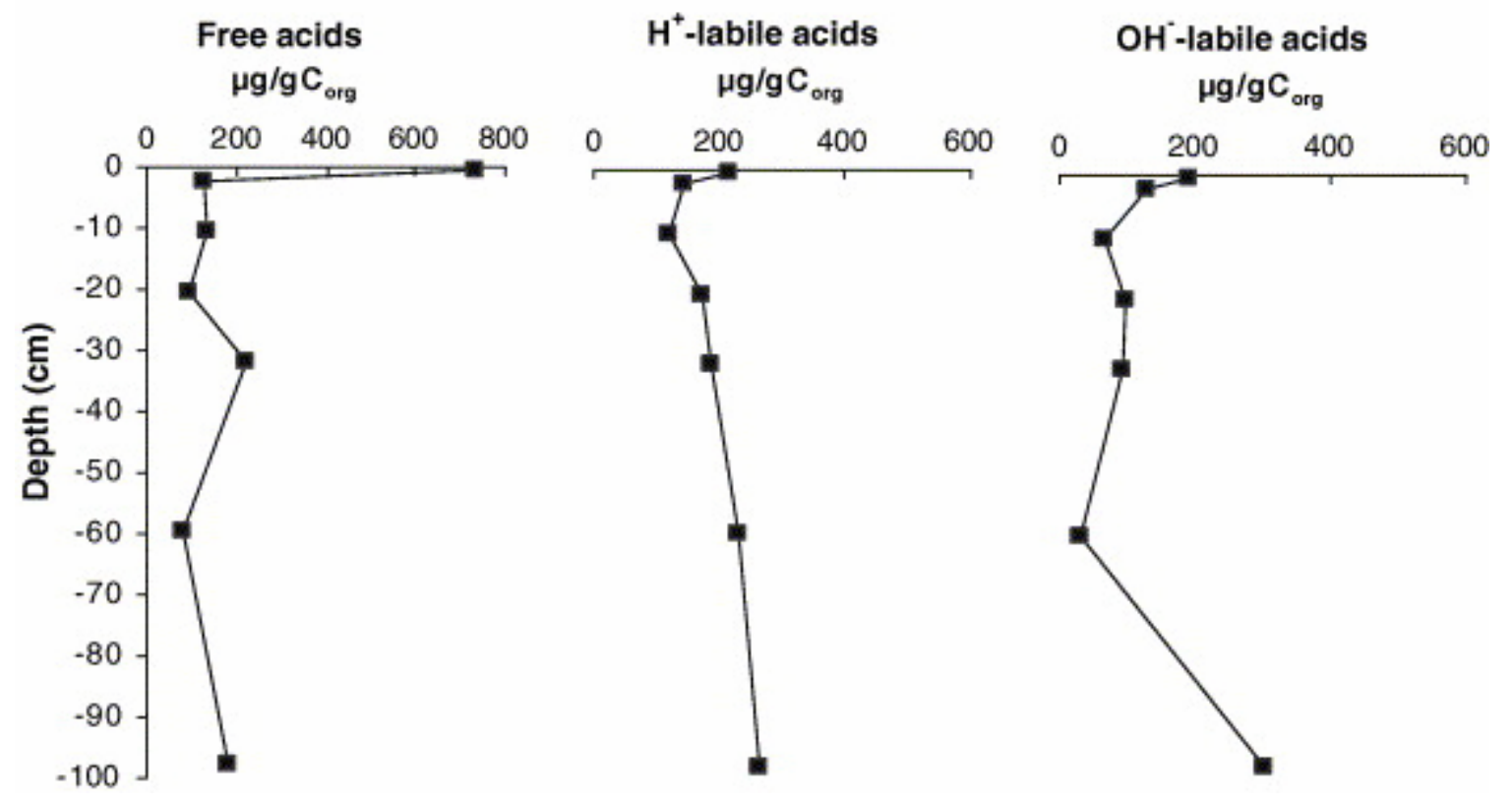

Fig. 1. FA concentration variation with depth. 


\begin{tabular}{|c|c|c|c|}
\hline \multirow[t]{2}{*}{ Compound type } & \multicolumn{3}{|l|}{ FA fraction ${ }^{\mathrm{a}}$} \\
\hline & Free & $\mathrm{H}^{+}$-labile & $\mathrm{OH}^{-}$-labile \\
\hline \multirow[t]{2}{*}{$n$-FAs (saturated) } & $n-\mathrm{C}_{14}-n-\mathrm{C}_{30}$ & $n-\mathrm{C}_{14}-n-\mathrm{C}_{30}$ & $n-\mathrm{C}_{14}-n-\mathrm{C}_{30}$ \\
\hline & $\left(n-C_{16}, 400 \mu g\right)$ & $\left(n-C_{16}, 100 \mu g\right)$ & $\left(n-C_{16}, 75 \mu \mathrm{g}\right)$ \\
\hline \multirow[t]{2}{*}{$n$-FAs (monounsaturated) } & $n-\mathrm{C}_{16: 1} ; n-\mathrm{C}_{18: 1}$ & $n-\mathrm{C}_{16: 1} ; n-\mathrm{C}_{18: 1}$ & $n-\mathrm{C}_{16: 1} ; n-\mathrm{C}_{18: 1}$ \\
\hline & $\left(n-\mathrm{C}_{18: 1}, 50 \mu \mathrm{g}\right)$ & $\left(n-C_{18: 1}, 42 \mu g\right)$ & $\left(n-\mathrm{C}_{18: 1}, 20 \mu \mathrm{g}\right)$ \\
\hline \multirow[t]{4}{*}{ Branched-FAs } & $i-\mathrm{C}_{15} ; i-\mathrm{C}_{16}$ & $i-\mathrm{C}_{15} ; i-\mathrm{C}_{16}$ & $i-\mathrm{C}_{15} ; i-\mathrm{C}_{16}$ \\
\hline & $\left(i-C_{16}, 4.6 \mu \mathrm{g}\right)$ & $\left(i-\mathrm{C}_{15} ; i-\mathrm{C}_{16}, 10 \mu \mathrm{g}\right)$ & $\left(i-\mathrm{C}_{15}, 30 \mu \mathrm{g}\right)$ \\
\hline & $a i-C_{15} ; a i-C_{16}$ & $a i-\mathrm{C}_{15} ; a i-\mathrm{C}_{16}$ & $a i-\mathrm{C}_{15} ; a i-\mathrm{C}_{16}$ \\
\hline & $\left(a i-C_{16}, 5.6 \mu \mathrm{g}\right)$ & $\left(a i-C_{15}, 20 \mu g\right)$ & $\left(a i-C_{15}, 5 \mu g\right)$ \\
\hline \multirow[t]{2}{*}{ 3-OH-FAs } & - & $3-\mathrm{OH}-\mathrm{C}_{14}, 40 \mu \mathrm{g}$ & $3-\mathrm{OH}-\mathrm{C}_{14}, 8 \mu \mathrm{g}$ \\
\hline & & $3-\mathrm{OH}-\mathrm{C}_{16}, 10 \mu \mathrm{g}$ & $3-\mathrm{OH}-\mathrm{C}_{16}, 5 \mu \mathrm{g}$ \\
\hline \multirow[t]{2}{*}{$\alpha, \omega$-dicarboxylic-FAs } & - & $\alpha, \omega-C_{16}, 15 \mu g$ & $\alpha, \omega-C_{16}, 102 \mu g$ \\
\hline & & & $\alpha, \omega-C_{20}, 17 \mu \mathrm{g}$ \\
\hline 17,21-seco-Hopanoic acid & $\mathrm{C}_{24}(12.8 \mu \mathrm{g})$ & $\mathrm{C}_{24}(12.2 \mu \mathrm{g})$ & $\mathrm{C}_{24}(13.0 \mu \mathrm{g})$ \\
\hline
\end{tabular}

${ }^{a}$ Compounds determined as methyl esters.

Table 1. : Acid series distributions: carbon range, dominant compound and maximal content ( $\mu \mathrm{g} / \mathrm{g} \mathrm{C}_{\text {org }}$ )

As illustrated in Fig. 2 for the upper- $(0-2 \mathrm{~cm})$, mid- $(30-34 \mathrm{~cm})$ and lower core (96$99 \mathrm{~cm}$ ) samples, respectively, $n$-saturated acids and especially $n-C_{16: 0}$ and $n-C_{18: 0}$ strongly dominate compound distributions. The contribution of different series of acids to the "free", $\mathrm{H}^{+}$-labile and $\mathrm{OH}^{-}$-labile acid fractions and their changes with burial depth are shown in Fig. 3. The main observation is that FA indicators of high biological activity (namely, branched and 3-OH FAs) were released after the acidic and basic treatments.

Hopanoic acids were represented by only one compound. This was tentatively identified as a $\mathrm{C}_{24}$ 17,21-seco-hopanoic acid from the spectrum that showed a molecular ion at 374 amu, loss of a $\mathrm{COOCH}_{3}$ group $\left(\mathrm{M}^{+}-59 ; \mathrm{m} / \mathrm{z} 315 ; 100 \%\right)$ and intensive ions at $\mathrm{m} / \mathrm{z} 191$ and $\mathrm{m} / \mathrm{z}$ 177. The presence of a seco-acid in recent sediments is not surprising. In the Miocene Clarkia deposit, Huang et al. (1996) identified a suite of seco-terpenoic acids having ursane, oleanane and friedelane skeletons, all attributed to higher plants on the basis of carbon isotopic data. In our study, the possible seco-hopanoic acid could derive from a previous hopanoic acid by microbial reworking. It is, however, slightly suspicious that the quantity of this acid appears neither influenced by extraction treatment nor by diagenesis (i.e., depth) since, except at the surface where it is present in slightly higher amounts (ca. 13$16 \mu \mathrm{g} / \mathrm{g} \mathrm{C}_{\text {org }}$ ), it represented $\sim 2 \%$ of all extracts, at all levels (Table 1). 


\section{Free acids}

Free acids, 0-2 cm

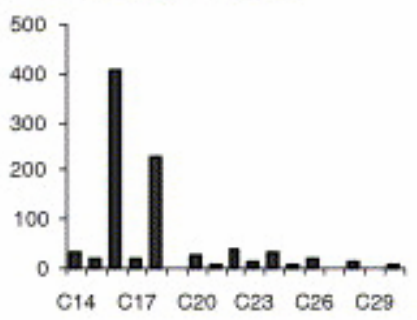

Free acids, $30-34 \mathrm{~cm}$

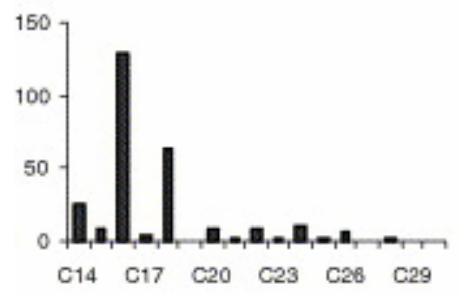

Free acids, $96-99 \mathrm{~cm}$

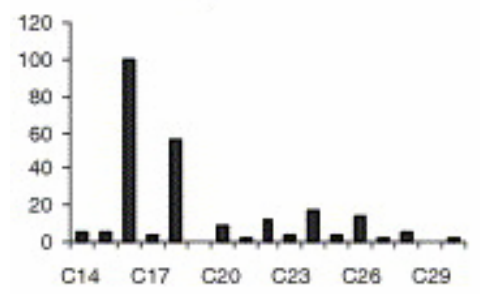

$\mathrm{H}^{+}$-labile acids

$\mathrm{H}^{+}, 0-2 \mathrm{~cm}$

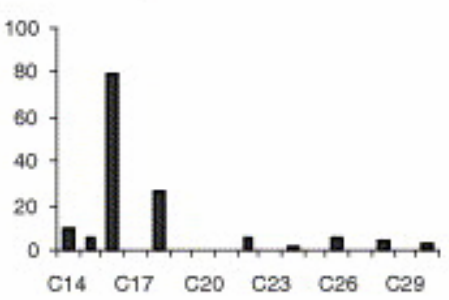

$\mathrm{H}^{+}, 30-34 \mathrm{~cm}$

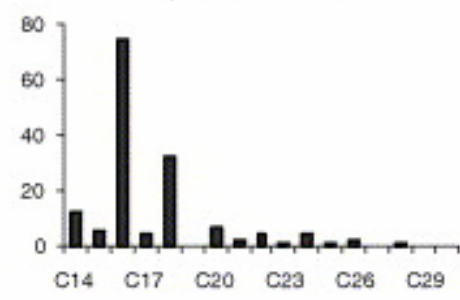

$\mathrm{H}^{+}, 96-99 \mathrm{~cm}$

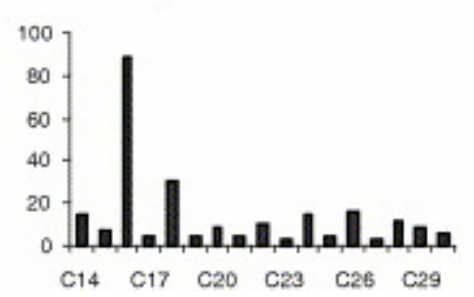

$\mathrm{OH}^{-}$-labile acids

$\mathrm{OH}^{-}, 0-2 \mathrm{~cm}$

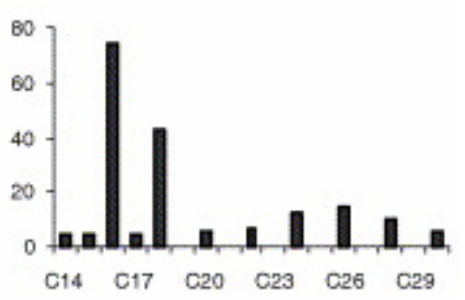

$\mathrm{OH}^{-}, 30-34 \mathrm{~cm}$

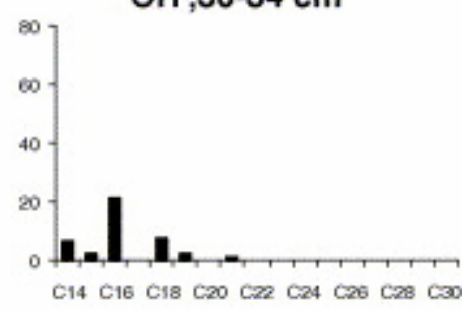

$\mathrm{OH}^{\circ}, 96-99 \mathrm{~cm}$

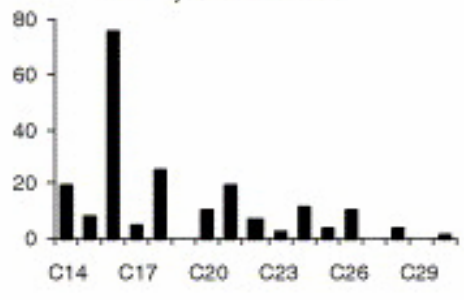

Fig. 2. Distributions of $n$-fatty acids $\left(\mu \mathrm{g} / \mathrm{g} \mathrm{C}_{\text {org }}\right)$ in "free" and "bound" acid fractions of upper-, mid- and downcore samples. 

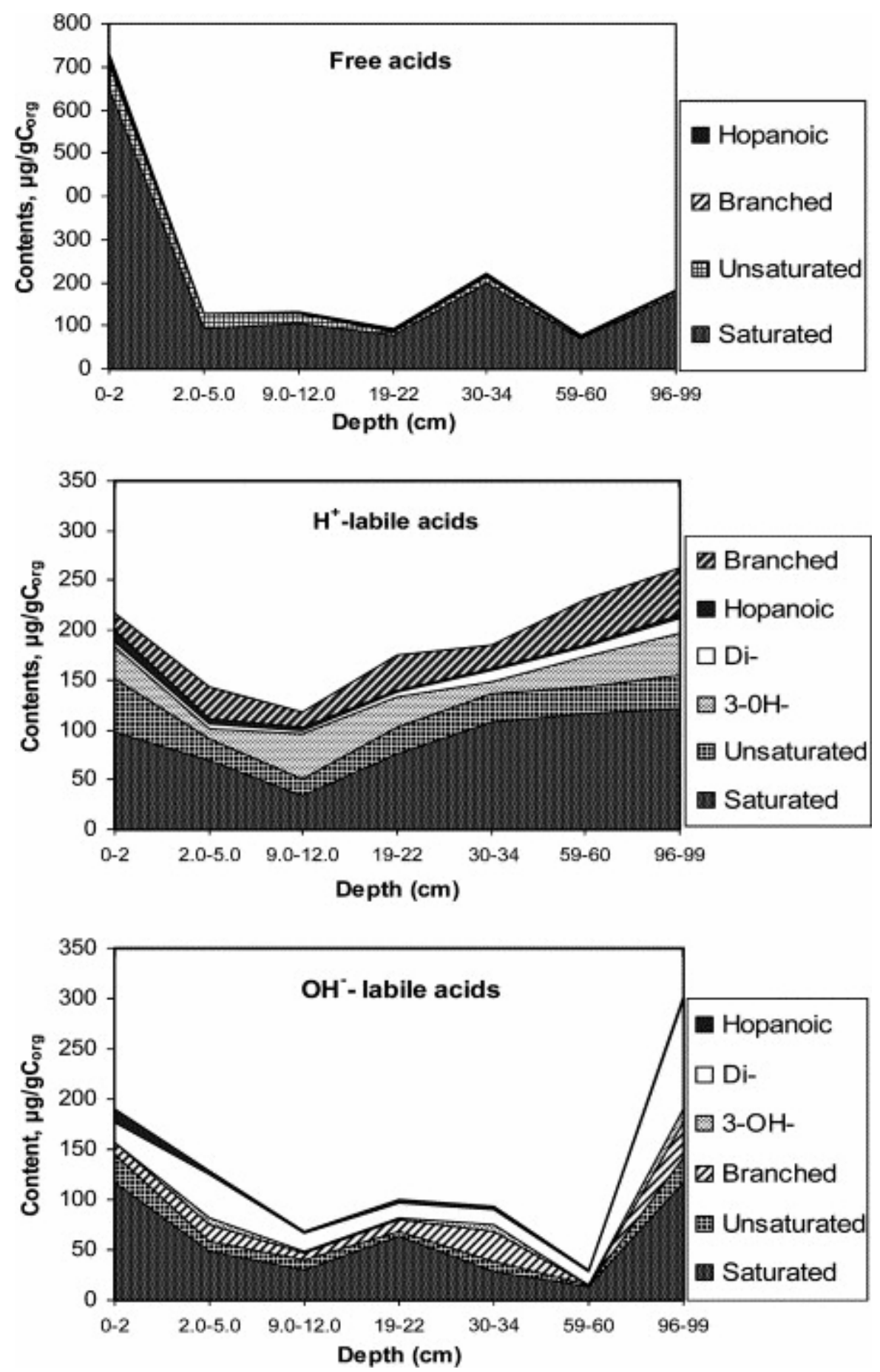

Fig. 3. Contributions of different series of FAs to "free" and "bound" lipids and variations with depth.

\subsection{FA variation with depth}

The following discussion on the biological origin of FAs and their variation with depth is focussed mostly on the analysis of the individual concentration profiles. Information deduced from their structure is often disputable because of the general multiplicity of possible source organisms. 


\subsubsection{Variation in total quantities of "free" and bound FAs}

The quantities of FAs represent the sum of the compounds identified using GC-MS and quantified using GC. Their variation with depth is presented in Fig. 1. The first notable point is the relatively high amount of "free" FAs in the surface sample. This demonstrates two essential facts: first, rapid hydrolysis of the ester (and amide) bonds of the various combinations under which FAs exist in living organisms and second, a temporary accumulation of "free" FAs at the surface of the sediment column. This second point further implies a faster release of FAs from their original combinations than their consumption by microorganisms. This latter phenomenon is nevertheless very rapid as proven by the abrupt decrease recorded by "free" FA concentrations between the surface and the immediately underlying level. Despite the relative speed of this consumption process, notable quantities of free FAs still exist at depth. These form a nearly continuous background all along the section. The stock that occurs at depth might either represent a transitory pool of compounds progressively liberated by hydrolysis of esters and/or amides and waiting to be degraded, or to a stock of FAs freed rapidly during early diagenesis and preserved as a result of the rapid disappearance of any noticeable biological activity at depth.

The initially bound acids released by $\mathrm{H}^{+}$and by $\mathrm{OH}^{-}$treatments display different profiles but show notable FA contents at almost all sedimentary levels. The persistence, if not the increase in the amounts of bound acids all along the profile, is consistent with an absence of degradation of bound (as well as of "free") acids at depth, or more precisely below $10 \mathrm{~cm}$. These various considerations suggest that, once past the phase of intensive degradation at the surface, the FAs are likely to preserve information on their environment of deposition during further burial. Thus, the relatively high amounts of "free" and $\mathrm{OH}^{-}$-labile FAs at 30-34 cm and 96-99 cm depth either denote particularly important inputs of these compounds and/or particularly favourable preservation conditions during deposition and early diagenesis. For the sample taken at $33-34 \mathrm{~cm}$, the former hypothesis is supported by independent observations revealing that the corresponding sediment was deposited under well oxygenated waters that were the site of a rather important production of diatoms and of the alga Botryoccoccus braunii (Bourdon, 1999 and Bourdon et al.. $\underline{2000})$.

\subsection{2. "Free" FA variation with depth}

The "free" FA fraction is dominated by low molecular weight linear saturated acids, i.e., $n-C_{16}$ and $n-C_{18}$ (Fig. 2 and Fig. 3 ). To a lesser extent these compounds are accompanied by their unsaturated homologues, $n-\mathrm{C}_{16: 1}$ and $n-\mathrm{C}_{18: 1}$ (Fig. $4 \mathrm{a}$ and $\mathrm{b}$ ). All these compounds are abundant in all living organisms (Matsuda and Koyama, 1977) but most particularly in phytoplankton (Cranwell, 1978, Cranwell, 1982 and Robinson et al., 1984) and even in bacteria (Holton and Blecker, 1970). They are accompanied by a relatively minor contribution from even numbered higher molecular weight saturated homologues, $n-C_{20+}$ that, in most cases are dominated by the $n-C_{24}$ component (Fig. 2). The latter are particularly abundant in terrestrial higher plants (Cranwell, 1978 and Cranwell, 1982). The "free" fractions also contain small proportions of $\mathrm{C}_{15}$ and $\mathrm{C}_{16}$ branched iso- and anteiso-compounds, namely $i-\mathrm{C}_{15}$, ai$\mathrm{C}_{15}, i-\mathrm{C}_{16}$ and $a i-\mathrm{C}_{16}$, that are usually considered as being derived from bacteria (Poupet, 1989 and Volkman et al., 1998). 
a

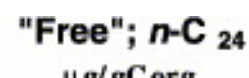

$\mu \mathrm{g} / \mathrm{gC}$ org

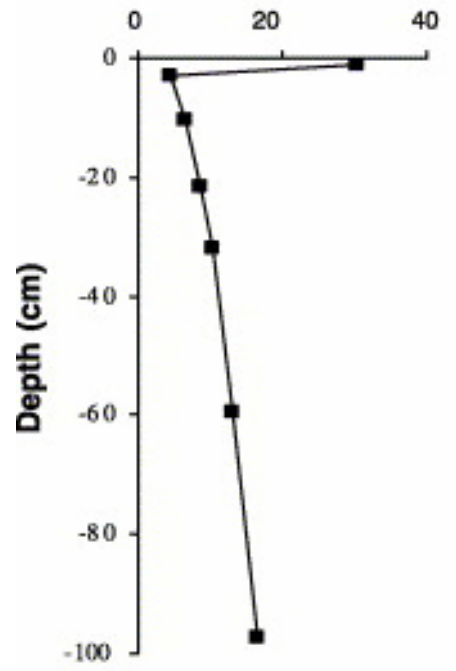

"Free"; n-C 18:1 $\mu \mathrm{g} / \mathrm{gCorg}$

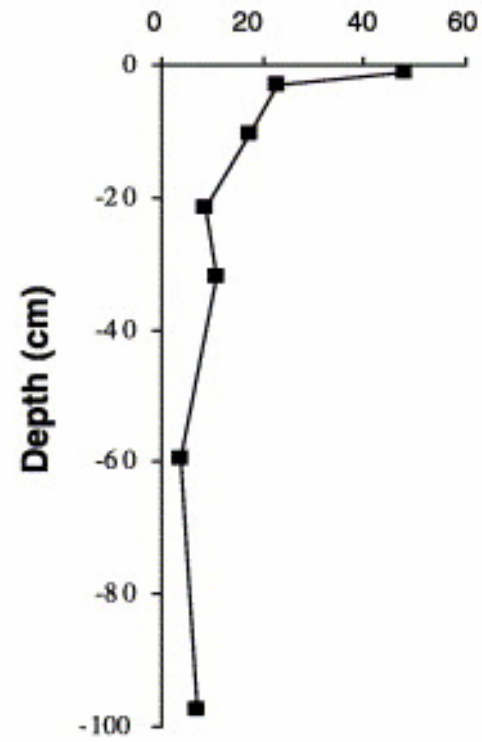

"Free"; $n-C_{18}$ $\mu \mathrm{g} / \mathrm{gC}$ org

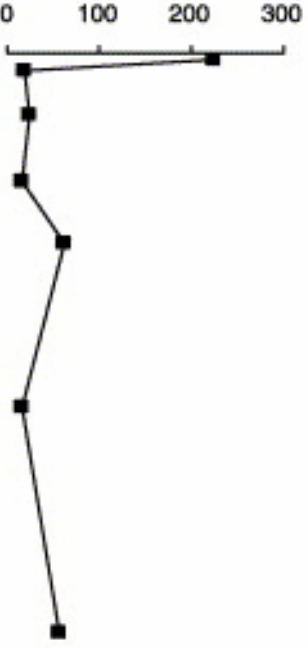

Free"; $n$-C 16 $\mu \mathrm{g} / \mathrm{gCorg}$

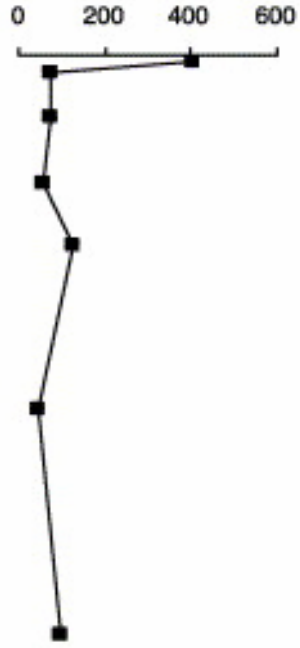

"Free"; n-C 16:1 $\mu \mathrm{g} / \mathrm{gC}$ org

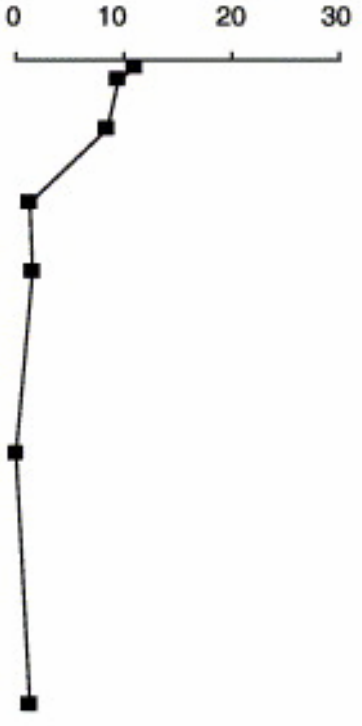

b "Free"; $\boldsymbol{i}-\mathbf{C}_{16}$ $\mu \mathrm{g} / \mathrm{gC}$ org

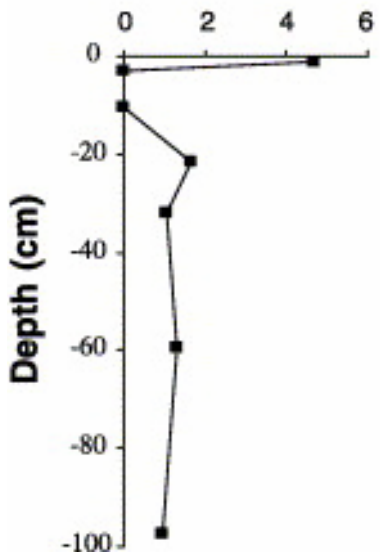

"Free"; $\boldsymbol{i}-\mathrm{C}_{15}$ $\mu \mathrm{g} / \mathrm{gC}$ org
"Free"; ai- $\mathrm{C}_{16}$ $\mu \mathrm{g} / \mathrm{gC}$ org
"Free"; ai- $\mathrm{C}_{15}$ $\mu \mathrm{g} / \mathrm{gCorg}$
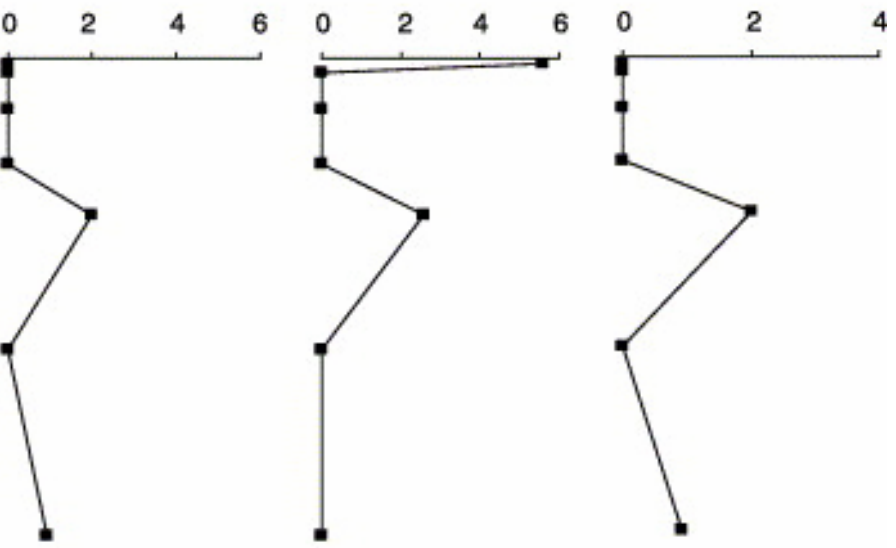

Fig. 4. (a,b) Downcore correlations of some fatty acids $\left(\mu \mathrm{g} / \mathrm{g} \mathrm{C}_{\text {org }}\right)$ in the "free" acid fraction. 
At the peat surface, the amounts of linear saturated FAs record a much stronger decrease (Fig. 4a) than their unsaturated counterparts despite the fact that the former are usually considered as more refractory with respect to biodegradation. This contradictory observation might tentatively be explained by a comparable rate of release of both types of compounds from their original lipid combinations, followed by a preferential consumption of the "free" unsaturated FAs that are more easily assimilated than their saturated counterparts. The lower abundance of the transitory stock of the latter necessarily entails a lower decrease in their amount during early diagenesis [i.e., between the surface $(0-1 \mathrm{~cm})$ and the immediately underlying subsurface level (2-5 cm depth)].

The concentration profiles of the "free" branched FAs thought to be derived from bacteria, show clear similarities, the profiles of $i-\mathrm{C}_{15}$ and $a i-\mathrm{C}_{15}$ being even strictly comparable with high compound amounts at ca. 32 and $98 \mathrm{~cm}$ depth (Fig. $4 \mathrm{~b}$ ). In contrast to $i-\mathrm{C}_{15}$ and $a i-\mathrm{C}_{15}, i-\mathrm{C}_{16}$ and $a i-\mathrm{C}_{16}$ are both present at the surface but do not maximise at the same depth intervals. All these observations indicate that there are at least three major sources (or levels of major production) for the four branched compounds: at the surface ( $i-$ and ai- $\left.\mathrm{C}_{16}\right)$, at ca. $20 \mathrm{~cm}\left(i-\mathrm{C}_{16}\right)$ and at ca. $32 \mathrm{~cm}$ (ai$\mathrm{C}_{16}, i-\mathrm{C}_{15}$ and $\left.a i-\mathrm{C}_{15}\right)$. Thus, the organisms that synthesised the ai- $\mathrm{C}_{16}$ obviously thrived at ca. $32 \mathrm{~cm}$ with those that synthesised the $i-\mathrm{C}_{15}$ and $a i-\mathrm{C}_{15}$, whereas the conditions that prevailed during deposition of the sedimentary material presently at ca. $98 \mathrm{~cm}$ depth were unfavourable for the ai- $\mathrm{C}_{16}$ producer(s).

Whereas all the already considered "free" FAs seem to have given rise to (an) accumulation(s) under specific medium conditions, the saturated acid $n-\mathrm{C}_{24}$ (taken as representative of all the even numbered $n-C_{20+}$ species) records first a drastic lowering in concentration just below the surface, then shows a downward regularly increasing, but progressively flattening concentration curve. This increase might be due to a progressive release of $n-\mathrm{C}_{24}$ by hydrolysis or even to its synthesis (very unlikely since this would entail a compound classically attributed to higher plants also being produced by microorganisms). The high abundance of $n-C_{24} F A$ in the bound form at the base of the section does not allow us to favour either of these two hypotheses.

\subsection{3. $\mathrm{OH}^{-}$-labile FA evolution with depth}

In contrast to the order of the extraction steps, we comment first on the evolution of the FAs liberated by classical saponification and supposed to arise from widespread lipid esters, then, we examine the data on FAs obtained by acid hydrolysis which are supposed to be specific for amide-bound compounds of bacterial origin (Mendoza et al., 1987a and Mendoza et al., 1987b).

All the major compounds that are present in the "free" state, namely the $n-C_{16}$ and $n$ $\mathrm{C}_{18}$ FAs, their monounsaturated counterparts $n-\mathrm{C}_{16: 1}$ and $n-\mathrm{C}_{18: 1}$ and their higher molecular weight homologues such as $n-C_{24}$, also exist in the fraction released by saponification (Fig. 5a). The high abundance of all these compounds at the sediment surface is fully consistent with an inheritance from organisms that grew in the marsh. As already assumed in the previous section, the important decrease in the abundance of these compounds between the surface sample and the immediately underlying level certainly results from microbial attack. At greater depth, the presence 
of saturated und unsaturated linear FAs in rather high concentration (especially at ca. $98 \mathrm{~cm}$ ) reveals episodes of high production and/or preservation of these compounds.

a $\mathrm{OH}^{*} ; n-\mathrm{C}_{16}$ $\mu \mathrm{g} / \mathrm{gCorg}$

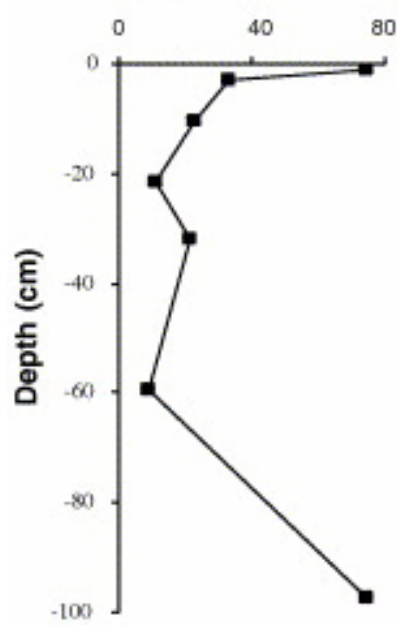

$\mathrm{OH}^{*} ; \boldsymbol{n}-\mathrm{C}_{16: 1}$ $\mu \mathrm{g} / \mathrm{gC}$ org

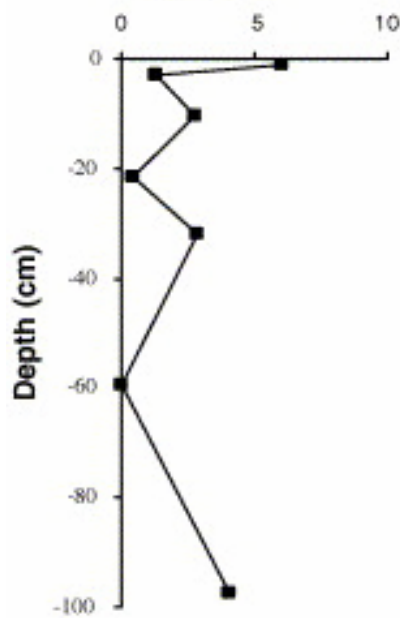

$\mathrm{OH}^{*} ; \boldsymbol{n}-\mathrm{C}_{18}$ $\mu \mathrm{g} / \mathrm{g}$ Corg

0

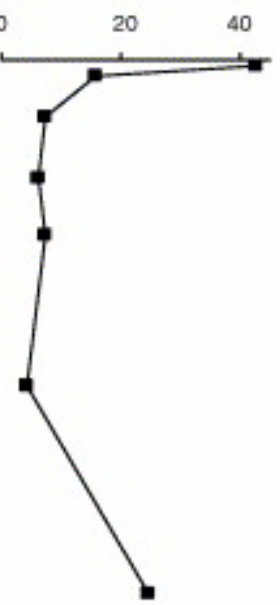

$\mathrm{OH}^{*} ; \boldsymbol{n}-\mathrm{C}_{18: 1}$

$\mu \mathrm{g} / \mathrm{g}$ Corg

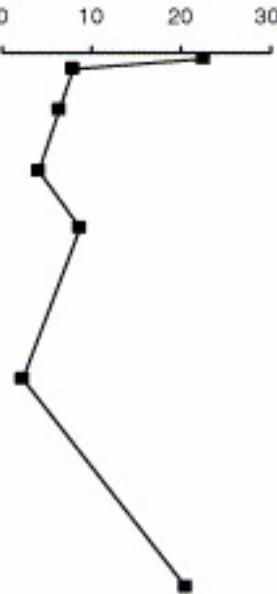

$\mathrm{OH}^{*} ; \boldsymbol{n}-\mathrm{C}_{24}$

$\mu \mathrm{g} / \mathrm{gCorg}$

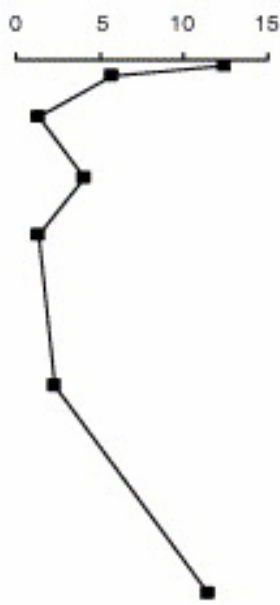

$\mathrm{OH}^{*} ; \mathrm{i}-\mathrm{C}_{16}$ $\mu \mathrm{g} / \mathrm{g}$ Corg

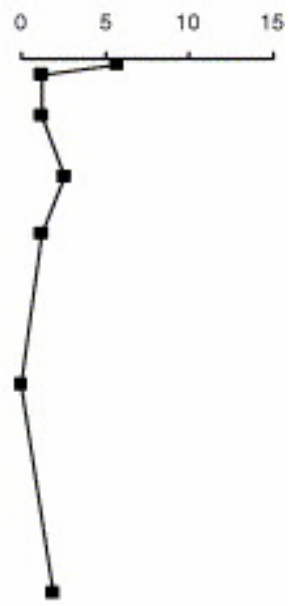



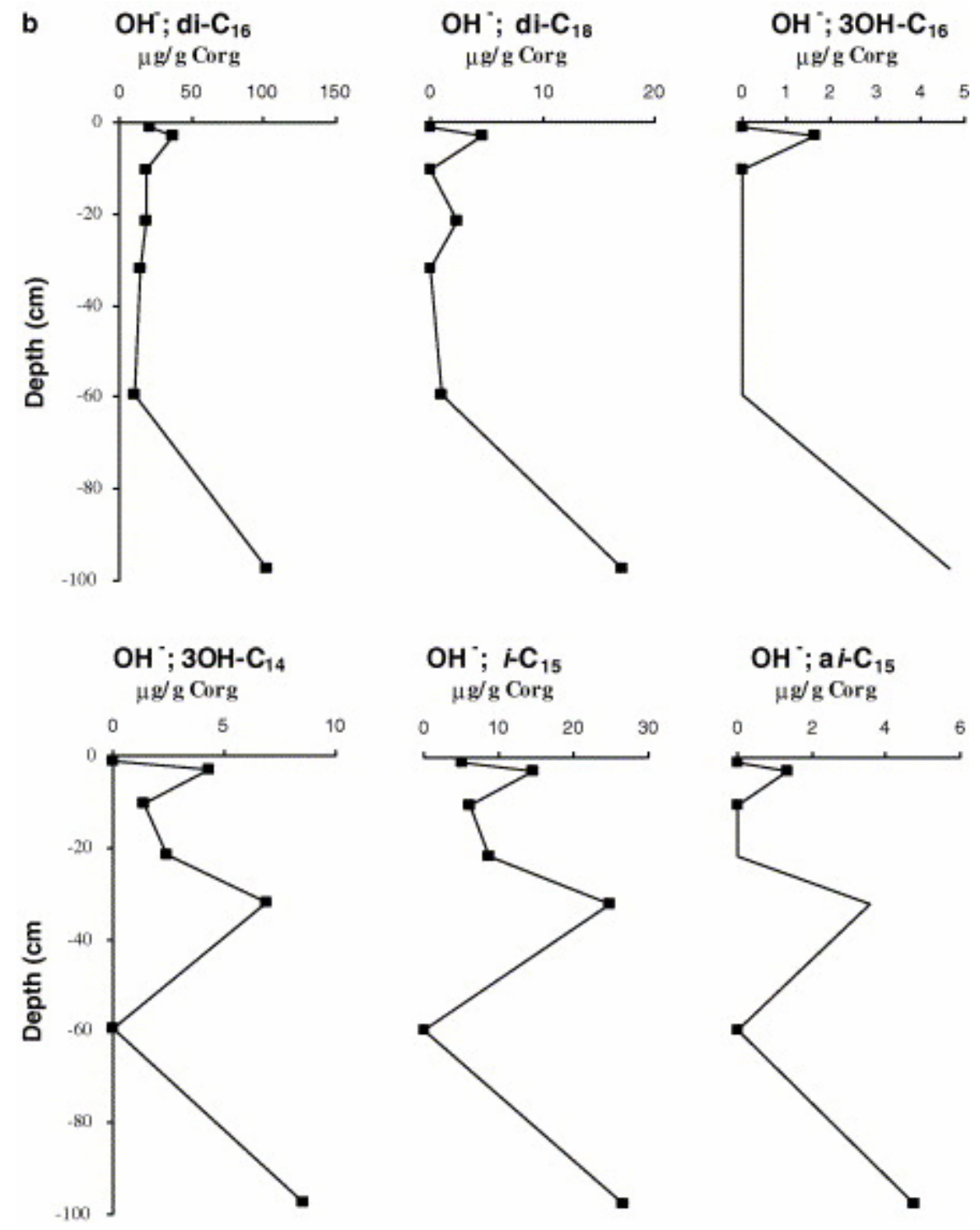

Fig. 5. (a,b) Downcore correlations of some fatty acids ( $\mu \mathrm{g} / \mathrm{g} \mathrm{Corg})$ in $\mathrm{OH}^{-}$-labile acid fraction.

Following the same interpretation as above, the strong decrease recorded by the branched acid $i-\mathrm{C}_{16}$ immediately below the surface (Fig. 5a) suggests it was also inherited from a primary producer, or more precisely from bacteria that thrived in the marsh waters, since branched FAs are generally supposed to be specific to such organisms (Poupet, 1989 and Volkman et al., 1998). The profile of this $i-C_{16}$ compound parallels that of the $n-C_{24}$ species. In other respects, it must be stressed that the concentration profile of the $n-C_{24}$ released by saponification is totally independent of that of the same compound in the free state (Fig. 4a). The absence of such a relationship makes the question of the origin of the "free" $n-C_{24}$ component even more puzzling.

The compounds that appear just below the surface (i.e., at $2-5 \mathrm{~cm}$ depth; Fig. $5 \mathrm{~b}$ ) are especially those which are usually considered as deriving from bacteria, such as the $i-\mathrm{C}_{15}$, ai- $\mathrm{C}_{15}$ and $3-\mathrm{OH}-\mathrm{C}_{14}$ acids. These three compounds show similar profiles, with high values at three different levels that strongly suggest that they have a common 
origin or simply that they derive from microorganisms that prosper under similar conditions.

The di- $\mathrm{C}_{16}$ and di- $\mathrm{C}_{18} \alpha \omega$-dicarboxylic acids have nearly identical profiles (Fig. $5 \mathrm{~b}$ ) as would be reasonably expected for compounds that most probably have the same source, namely higher plant cuticles (Kolattukudy et al., 1976). These diacids appear in the sub-surface (i.e., at ca. $5 \mathrm{~cm}$ ) but disappear almost completely afterwards, maybe as a result of rapid degradation. Nevertheless, they are both abundant at $98 \mathrm{~cm}$ depth, thus probably providing additional evidence that this level has been the site of good organic matter preservation (Bourdon, 1999).

\subsection{4. $\mathrm{H}^{+}$-labile FA evolution with depth}

The dominant compounds in this fraction are the lower molecular weight saturated acids, $n-C_{16}$ and $n-C_{18}$, as well as the unsaturated $n-C_{18: 1}$ acid. The profiles of these three compounds appear relatively well correlated, but with slightly higher values for the $n-C_{18}$ species at ca. $32 \mathrm{~cm}$ than at ca. $98 \mathrm{~cm}$ (Fig. 6a). These three profiles can probably be explained by the fact that all these very common FAs can be derived from multiple sources. The $n-C_{24}$ and $n-C_{16: 1}$ profiles (Fig. $6 \mathrm{~b}$ ) show first a strong decrease attributable to the rapid degradation of a stock inherited from primary producers and second a rather regular increase with increasing depth that leads us to hypothesise an in situ production of these compounds at depth. The other components of the fraction, i.e., mostly the $C_{15}$ and $C_{16}$ branched acids and the 3$\mathrm{OH}-\mathrm{C}_{16} \mathrm{FA}$, are more abundant at the sub-surface than at the surface, consistent with a secondary (microbial) origin. The notable decline that immediately follows their production stage can be interpreted as consequential to the immediate degradation of a notable part or even the totality of the primary stock. Below, i.e., beyond the first $10 \mathrm{~cm}$, the profiles of the $i-\mathrm{C}_{16}, 3-\mathrm{OH}-\mathrm{C}_{16}$ and di- $\mathrm{C}_{16}$ compounds resemble those of the $n-\mathrm{C}_{16}, n-\mathrm{C}_{18}$ and $n-\mathrm{C}_{18: 1}$ acids discussed above, but with a more pronounced increase with increasing depth (Fig. 6b). In fact, these profiles, which seem to tend to an asymptote at depth, might well evoke an efficient but progressively declining in situ (i.e., bacterial) production. The putative bacteria might be dead or alive, and in the second case might be active or only subsisting in a latent state (Given et al., 1983 and $\underline{\text { Chasar et al., 2000). }}$. 
a $\quad \mathrm{H}^{+} ; n-\mathrm{C}_{18 ; 1}$ $\mu \mathrm{g} / \mathrm{gCorg}$

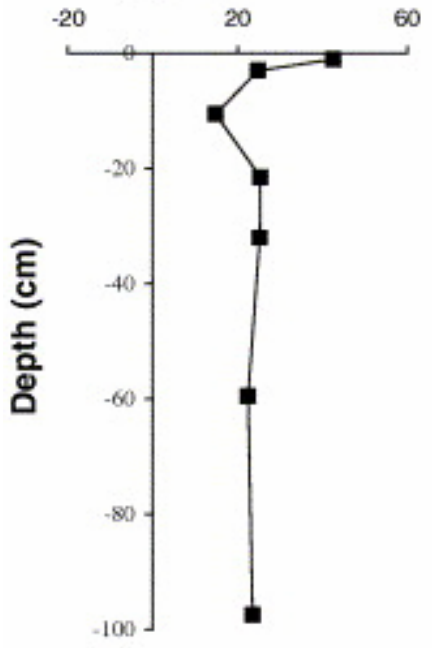

$\mathrm{H}^{+} ; \mathrm{i}-\mathrm{C}_{16}$ $\mu \mathrm{g} / \mathrm{gCorg}$

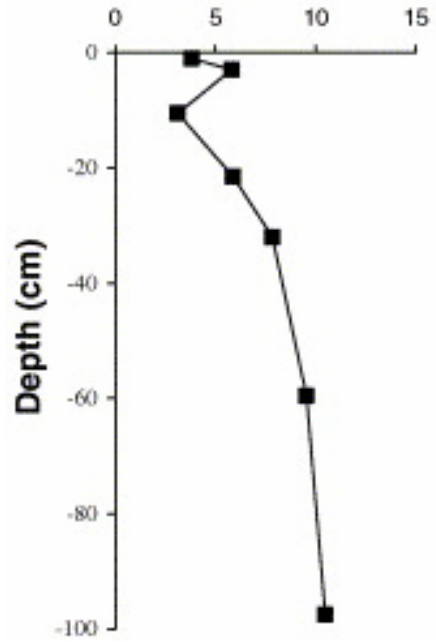

$\mathrm{H}^{+} ; \boldsymbol{n}-\mathrm{C}_{16}$ $\mu \mathrm{g} / \mathrm{gCorg}$

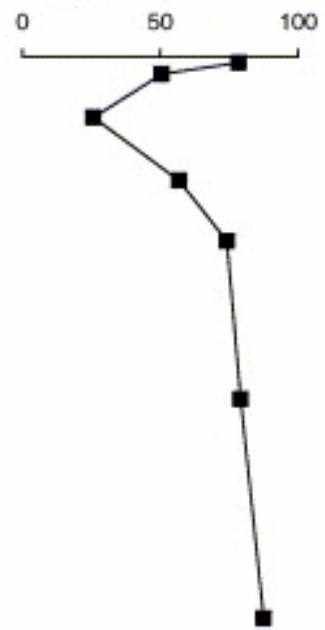

$\mathrm{H}^{+}$; 3-OH- $\mathrm{C}_{16}$ $\mu \mathrm{g} / \mathrm{gCorg}$

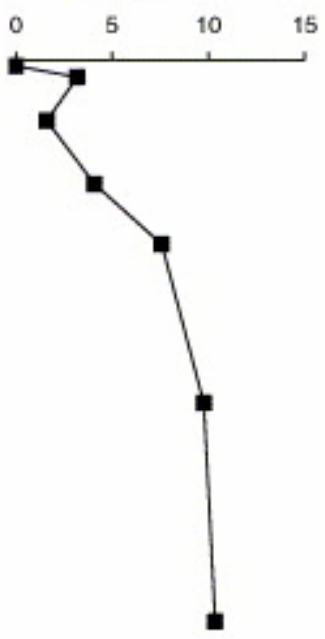

$\mathrm{H}^{+} ; \boldsymbol{n}-\mathrm{C}_{18}$ $\mu \mathrm{g} / \mathrm{gCorg}$

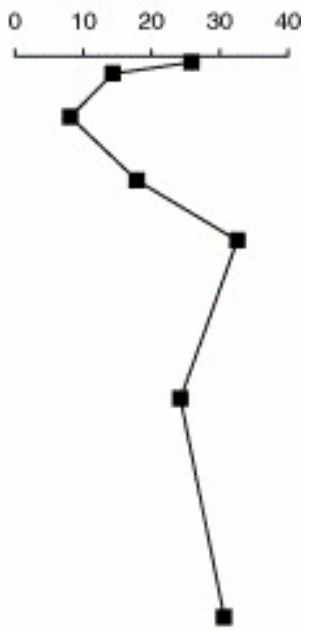

$\mathrm{H}^{+}$; di-C $\mu \mathrm{g} / \mathrm{g}$ Corg

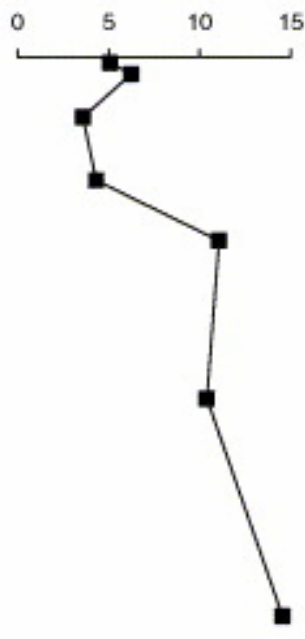



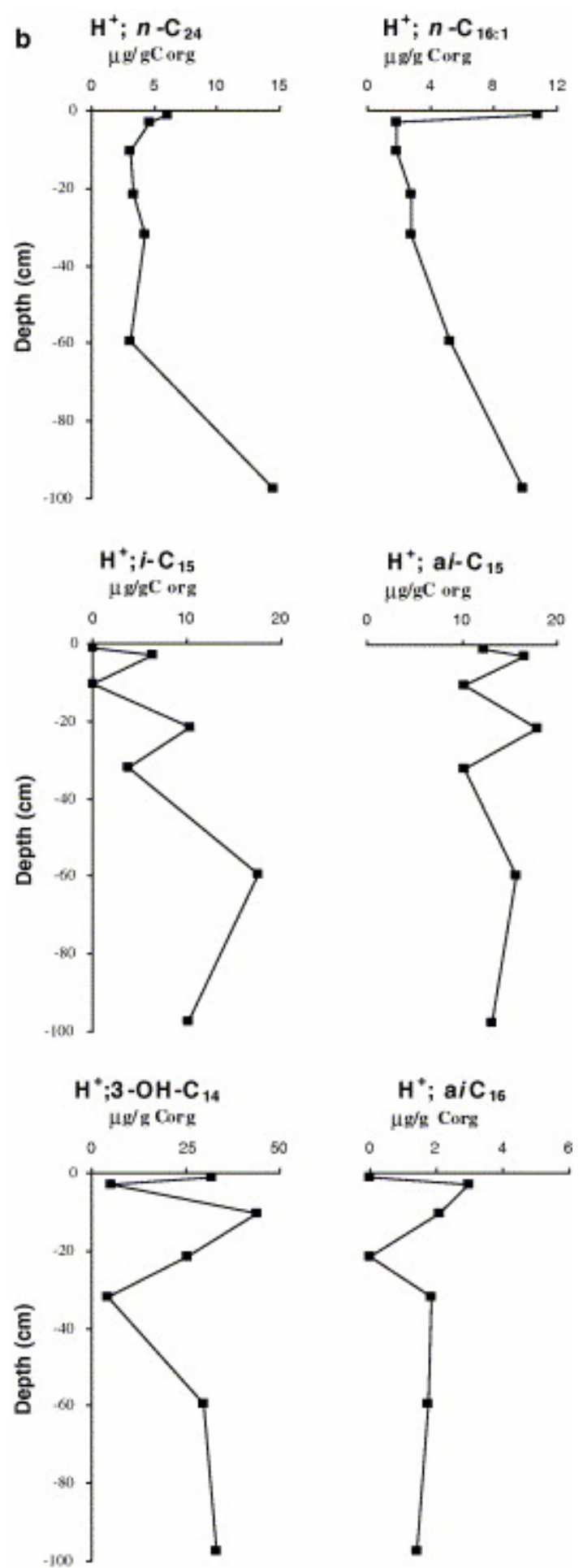

Fig. 6. $(\mathrm{a}, \mathrm{b})$ Downcore correlations of some fatty acids $\left(\mu \mathrm{g} / \mathrm{g} \mathrm{C}_{\text {org }}\right)$ in $\mathrm{H}^{+}$-labile acid fraction. 
The profiles of the $i-\mathrm{C}_{15}$ and $a i-\mathrm{C}_{15}$ acids, which are well correlated (Fig. 6b), denote a production just below the surface and additional episodes of compound production or rather good preservation at 20 and $60 \mathrm{~cm}$. This pattern, just the reverse of the one produced by the same acids released by saponification, suggests a multiplicity of bacterial sources that compete one with an other depending on conditions (and/or timing of diagenesis).

\section{General discussion}

In the following, the possibility of incorporation of some FAs into newly formed compounds, namely humic substances, is not discussed. Such a possibility should not be omitted but first, it can be considered as a kind of preservation mechanism and second, at least for the less common compounds, it is contradicted by a complete lack of FA at some levels, in one or several fractions.

As assumed in the previous sections, the most reliable indications of inherited FAs should be found in the $\mathrm{OH}^{-}$-labile fraction since this one should comprise all the compounds freed from different kinds of esters that constitute the most important lipid fractions of living organisms. A major difference between all the compound concentration profiles drawn for that fraction can, at least to a first indication, be seen as typical evidence of primary or secondary production. Thus, compounds present in high proportion at the surface (e.g., $n-\mathrm{C}_{16}$ and $i-\mathrm{C}_{16}$; Fig. $5 \mathrm{a}$ ) can be considered as being inherited from the primary production. In contrast, the compounds that are nearly totally absent at the surface but which are abundant in the immediately underlying level might be revealing an in situ secondary production (namely 3-OH$\mathrm{C}_{14}, i$ - and ai- $\mathrm{C}_{15}$; Fig. $5 \mathrm{~b}$ ).

All the compounds considered as issuing from the primary producers are also present in high relative proportions in the "free" fraction, including $i-\mathrm{C}_{16}$ and even its ai isomer (Fig. 4b) that was undetectable in the $\mathrm{OH}^{-}$-labile fraction. This is fully consistent with the release of "free" FAs presumably by (microbial) ester and/or amide bond hydrolysis in the very early stages of diagenesis. The only compounds attributed to secondary production in the $\mathrm{OH}^{-}$-labile fraction and that also exist in the "free" fraction are the $i$ - and ai- $\mathrm{C}_{15}$ acids. However, these compounds were not observed in the free state at the subsurface as in $\mathrm{OH}^{-}$-labile fraction but only at depth (i.e., 32 and $98 \mathrm{~cm}$ ). This might indicate a rather slow release of these compounds from their original combinations, i.e., in a more general way, much slower hydrolysis occurring in the sediment than in the surface waters as a result of much reduced microbial activity. This is in a certain way confirmed by the absence from the "free" fraction of other compounds that were also found at the subsurface in the $\mathrm{OH}^{-}$-labile fraction and that were thus supposed to be derived from secondary production, namely $\mathrm{OH}-\mathrm{FAs}$ and di-acids. The polyfunctional nature of these compounds might at least partly explain their rather more difficult release than for simple FAs.

The abundance of all primary as well as secondary products at ca. $98 \mathrm{~cm}$ provides evidence for very good OM preservation conditions during the deposition of this section. In contrast, the sample from ca. $32 \mathrm{~cm}$ depth is only rich in secondary products, i.e., $i$ - and $a i-\mathrm{C}_{15}$, plus $3-\mathrm{OH}-\mathrm{C}_{14}$. In fact, it has previously been shown (Bourdon, 1999 and Laggoun-Défarge et al., 1999) that this level was particularly rich in mucilage, an extracellular polysaccharidic secretion (EPS) that can be produced 
not only by plant roots, but also by bacteria and fungi (Leppard et al., 1977, Decho, 1990 and Défarge et al., 1996). A notable fungal activity could be consistent with (i) the absence of di-acids and $3-\mathrm{OH}-\mathrm{C}_{16}$ of supposed bacterial origin and (ii) notable lignin degradation (Bourdon, 1999 and Bourdon et al., 2000).

Except for the presence of minor amounts $n-\mathrm{C}_{24}$, di- $\mathrm{C}_{18}$ and $i-\mathrm{C}_{16}$, the general paucity of FAs in the $\mathrm{OH}^{-}$-labile fraction of the sample taken at ca. $22 \mathrm{~cm}$ suggests that it has been the site of more extensive degradation than at $32 \mathrm{~cm}$. Even more extensive degradation might have occurred at 10 and $60 \mathrm{~cm}$ where almost all compounds are missing from the "free" (Fig. 4a and b) as well as from the $\mathrm{OH}^{-}$-labile fraction (Fig. 5a and $b$ ), with only one notable exception for the $n-\mathrm{C}_{24} \mathrm{FA}$ (and its $\mathrm{C}_{20+}$ homologues). For this compound, a significant release at the surface (certainly followed by rapid consumption) is followed by what seems to be a very slow release with increasing depth. In the absence of a much more plausible explanation this regular pattern was previously attributed (Section $\underline{3.2 .2}$ ) to possible in situ microbial production.

Acid hydrolysis is supposed to preferentially cleave the amide bonds that are important in bacterial lipids. Several of the compounds released in this way, and especially most of the more abundant ones, show a more or less regular increase with depth, namely $n-\mathrm{C}_{16}, n-\mathrm{C}_{18}, i-\mathrm{C}_{16}, 3-\mathrm{OH}-\mathrm{C}_{16}$ and di- $\mathrm{C}_{16}$ (Fig. 6a). Irregularities in this trend can be attributed to the influence of non-microbial sources. For example for the $n-C_{16}$ and $n-C_{18}$, the most ubiquitous of the considered compounds, the high proportions in the uppermost levels can simply be explained by their partial release from lipid esters abundant in all organisms, especially higher plants. A comparable explanation might hold for $i-\mathrm{C}_{16}, 3-\mathrm{OH}-\mathrm{C}_{16}$ and di- $\mathrm{C}_{16}$ acids (Fig. 6a) but with sources other than the previous compounds since, contrary to these latter ones, they are more abundant in the subsurface sample than in the surface one. The notable decrease in their quantity recorded below the subsurface level at ca. $2 \mathrm{~cm}$ depth and the onset of a regular increase from $10 \mathrm{~cm}$ depth, suggests that they are produced during two successive stages and at different rates, i.e., rapidly during very early diagenesis (at about $2 \mathrm{~cm}$ ) and slowly more deeply. The question as to whether these two production episodes are due to the same or different organisms remains unclear. However, the progressive flattening in the compound concentration vs. depth curves indicates that the inferred late bacterial production slows down progressively with increasing time.

Once the stage of surface release is past, the $n-C_{24}$ and $n-C_{16: 1}$ acids provide a completely different pattern from the previous compounds since the amounts of these two in the $\mathrm{H}^{+}$-labile fraction seem to increase progressively with depth (Fig. 6b). The interpretation of such a pattern is not straightforward. It can tentatively be assumed that it could result from a competition between the release of the two considered compounds from combined state and their subsequent consumption, the latter proceeding at a faster rate in the upper levels than at depth, consistent with a progressive decline in microbial activity with time. Even if the assumed pattern is not so clear for the $n-C_{24}$ component, the proposed interpretation is strengthened by the indication of a notable but declining production of this compound at depth, as provided by the "free" fraction (Fig. 4a). In contrast to the already considered compounds in the $\mathrm{H}^{+}$-labile fraction, the $i-\mathrm{C}_{15}$, ai- $\mathrm{C}_{15}, 3-\mathrm{OH}-\mathrm{C}_{14}$ and ai- $\mathrm{C}_{16}$ acids display very irregular patterns (Fig. $6 \mathrm{~b}$ ) The $3-\mathrm{OH}-\mathrm{C}_{14}$ acid is present in notable proportion at the surface but also at $10 \mathrm{~cm}$ where the absence of any compound in 
the "free" as well as in the $\mathrm{OH}^{-}$-labile fraction suggests extensive degradation. If the profile of the ai- $\mathrm{C}_{16}$ acid is little informative, it is worth mentioning that the $i$ - and ai$\mathrm{C}_{15}$ acids are relatively abundant at $2 \mathrm{~cm}$ depth, as in the $\mathrm{OH}^{-}$-labile fraction, but below this, have completely opposite patterns, i.e., high levels at ca. 22 and $60 \mathrm{~cm}$ (Fig. 6b) against maxima at 32 and $98 \mathrm{~cm}$ in the $\mathrm{OH}^{-}$-labile fraction (Fig. 5b). These observations provide clear evidence that these two branched isomers certainly exist under different combinations in microorganisms and additionally that these organisms (whatever they are) do not produce the $i$ - and $a i-C_{16}$ higher homologues.

Following the hypothesis of a late and slow third production, if the profile of the 3-OH$\mathrm{C}_{16} \mathrm{FA}$ at depth is considered as a bacterial growth curve, the "half-growth depth" occurs at about $20 \mathrm{~cm}$, thus entailing a half-growth time of about $500 \mathrm{yr}$ if the accumulation rate remained constant during deposition of the section presently between 0 and $32 \mathrm{~cm}$. If this interpretation is correct, it remains to be seen whether such a late bacterial growth is common in peat deposits or is due to local (normal or fortuitous) environmental factors. The hypothesis of an important and widespread microbial production at depth in peat deposits is supported by the recent determination of more than 20 times higher amounts of amino acids at depth in a Swiss peat than at the surface (Comont and Gautret; personal communication).

\section{Conclusions}

1. High amounts of "free" and $\mathrm{OH}^{-}$-labile FAs (saturated and unsaturated $n$-FAs, plus $i-\mathrm{C}_{16}$ ) at the surface of the peat sequence and low amounts in the immediately underlying level indicate rapid hydrolysis of lipid esters inherited from the primary production, followed by slightly slower consumption.

2. A whole range of $\mathrm{OH}^{-}$-labile $\mathrm{FAs}$ (diacids, $i$ - and $a i-\mathrm{C}_{15}, 3-\mathrm{OH}-\mathrm{C}_{14}$ ) that are almost or even totally absent from the peat surface, but are abundant in the immediate subsurface before decreasing just below, denote in situ secondary production and subsequent decay. All these compounds are totally missing from the "free" fraction of the surface sample.

3. Once past the upper levels where FA dynamics are very active in response to primary inputs, secondary production and active diagenesis, most of the $\mathrm{H}^{+}$-labile FAs attest to an important but late in situ microbial production that slows down progressively with increasing depth. The latter can be considered as a third production.

4. In contrast, compounds such as $i-\mathrm{C}_{15}$ and $a i-\mathrm{C}_{15}$ acids also released by acid hydrolysis and which are abundant in the immediate sub-surface but vary very irregularly at depth, might be inherited from consumers acting as secondary producers. In fact, these compounds maximise at levels (ca. 30 and $60 \mathrm{~cm}$ ) containing low amounts of "free" and $\mathrm{OH}^{-}$-labile FAs normally inherited from the primary producers.

5. Good OM preservation conditions (e.g., at ca. $98 \mathrm{~cm}$ depth) are indicated by high relative amounts of nearly all compounds, especially in the "free" and $\mathrm{OH}^{-}$-labile fraction (i.e., inherited from the primary as well as from the secondary producers, consumers included). 
6. The comparison of compound concentration profiles permits recognition of whether compounds are related to each other or not, i.e., whether they have the same source (e.g., $i$ - and $\left.a i-C_{15}\right)$, or are independent.

7. Active molecular dynamics during diagenesis do not allow the drawing of reliable geochemical interpretation for isolated recent geological samples (sediments or soils) after FA analysis. In other words, as formulated in a previous study on lake sediments (Stefanova and Disnar, 2000), extensive diagenesis can provoke the disappearance of most fatty acids and thus nearly all information on the contributing organisms except the latest consumers-producers, i.e., methanotrophs.

\section{Acknowledgements}

The authors express their sincere thanks to Prof. J.R. Maxwell and to two anonymous referees for their helpful comments.

\section{References}

Albaigés et al., 1984 J. Albaigés, J. Albaga and J. Grimalt, Extractable and bound lipids in some lacustrine sediments. In: P.A. Schenck, J.W. de Leeuw and G.W.M. Limbach, Editors, Advances in Organic Geochemistry 1983, Organic Geochemistry vol. 6, Pergamon Press, Oxford (1984), pp. 223-236.

Amblès et al., 1987 A. Amblès, G. Dupas and J.C. Jacquesy, Solubilization of Timahdit (Morocco) oil shale kerogen catalysed by 18-crown-6, Tetrahedron Letters 28 (1987), pp. 6449-6452.

Barnes and Barnes, 1978 M.A. Barnes and W.C. Barnes, Organic compounds in Lake Sediments. In: A. Lerman, Editor, Lakes. Chemistry Geology Physics, Springer, Berlin (1978), pp. 127-152.

Bourdon, 1999 Bourdon, S., 1999. Approches micromorphologiques et moléculaires de la diagenèse précoce de la matière organique dans une tourbière à Cypéracées en milieu tropical (Tritrivakely, Madagascar). Implications paléoenvironnementales. PhD Thesis, University of Orléans.

Bourdon et al., 1997 S. Bourdon, F. Laggoun-Défarge and C. Chenu, Effets de la diagenése précoce sur la matière organique sédimentaire d'origine palustre. Exemple du lac Tritrivakely (Madagascar), Bulletin de la Société Géologique de France 168 (1997), pp. 565-572.

Bourdon et al., 2000 S. Bourdon, F. Laggoun-Défarge, J.R. Disnar, O. Maman, B. Guillet, S. Derenne and C. Largeau, Organic matter sources and early diagenetic degradation in a tropical peaty marsh (Tritrivakely, Madagascar). Implications for environmental reconstruction during Sub-Atlantic, Organic Geochemistry 31 (2000), pp. 421-438. 
Burney, 1987 D.A. Burney, Pre-settlement vegetation changes at Lake Tritrivakely, Madagascar. In: J.A. Coetze, Editor, Palaeoecology of Africa, Balkema, Amsterdam (1987), pp. 351-381.

Chaperon et al., 1993 P. Chaperon, J. Danioux and L. Ferry, Fleuves et Rivières de Madagascar, ORSTOM, Paris (1993).

Chasar et al., 2000 L.S. Chasar, J.P. Chanton, P.H. Glaser, D.I. Siegel and J.S. Rivers, Radiocarbon and stable carbon isotopic evidence for transport and transformation of dissolved organic carbon, dissolved inorganic carbon, and $\mathrm{CH}_{4}$ in a northern Minnesota Peatland, Global Biogeochemical Cycles 14 (2000), pp. 10951108.

Cranwell, 1978 P.A. Cranwell, Extractable and bound lipid components in a freshwater sediment, Geochimica et Geochimica Acta 42 (1978), pp. 1523-1532.

Cranwell, 1982 P.A. Cranwell, Lipids of aquatic sediments and sedimenting particulates, Progress in Lipid Research 21 (1982), pp. 271-308.

Decho, 1990 A.W. Decho, Microbial exopolymer secretions in ocean environments: their role(s) in food webs and marine processes, Annual Review of Oceanography and Marine Biology 28 (1990), pp. 73-153.

Défarge et al., 1996 C. Défarge, J. Trichet, A.-M. Jaunet, M. Robert, J. Tribble and F.J. Sansone, Texture of microbial sediments revealed by cryo-scanning electron microscopy, Journal of Sedimentary Research 66 (1996), pp. 935-947.

Dehmer, $1993 \mathrm{~J}$. Dehmer, Petrology and organic geochemistry of peat samples from a raised bog in Kalimantan (Borneo), Organic Geochemistry 20 (1993), pp. 349-362.

Duan and Ma, 2001 Y. Duan and L. Ma, Lipid geochemistry in a sediment core from Ruoergai Marsh deposit (Eastern Qinghai-Tibet plateau, China), Organic Geochemistry 32 (2001), pp. 1429-1442.

Farrimond and Flanagan, 1995 P. Farrimond and R.L. Flanagan, Lipid stratigraphy of a Flandrian peat bed (Northumberland, UK): comparison with the pollen record, Holocene 6 (1995), pp. 69-74.

Ficken et al., 1998 K.J. Ficken, K.E. Barber and G. Eglinton, Lipid biomarkers, $\delta^{13} \mathrm{C}$ and plant macrofossil stratigraphy of a Scottish montane peat bog over the last two millenia, Organic Geochemistry 28 (1998), pp. 217-237.

Garcette-Lepecq et al., 2004 A. Garcette-Lepecq, C. Largeau, I. Bouloubassi, S. Derenne, A. Saliot, A. Lorre and V. Point, Lipids and their modes of occurrence in two surface sediments from the Danube delta and northwestern Black Sea: implications for sources and early diagenetic alteration I. Carboxylic acids, Organic Geochemistry 35 (2004), pp. 959-980. 
Gasse and Van Campo, 1998 F. Gasse and E. Van Campo, A 40,000-yr pollen and diatom record from lake Tritrivakely, Madagascar, in the southern tropics, Quaternary Research 49 (1998), pp. 299-311.

Gasse et al., 1994 F. Gasse, E. Cortijo, J.R. Disnar, L. Ferry, E. Gibert, C. Kissel, F. Laggoun-Défarge, E. Lallier-Vergès, J.-L. Saos, A. Sifeddine, M. Taieb, P. Tucholka, E. Van Campo and D. Williamson, A 36 kyear environmental record in the southern tropics: lake Tritrivakely (Madagascar), Comptes Rendus de l'Académie des Sciences (Paris) 318 (1994), pp. 1513-1519.

Given et al., 1983 P.H. Given, W. Spackman, J.R. Imbalzano, D.J. Casagrande, A.J. Lucas, W. Cooper and C. Exachos, Physicochemical characteristics and levels of microbial activity in some Florida peat swamps, International Journal of Coal Geology 3 (1983), pp. 77-99

Goossens et al., 1989a H. Goossens, J.W. de Leeuw, W. Irene, C. Rijpstra, G.J. Meyburg and P.A. Schenck, Lipids and their mode of occurrence in bacteria and sediments I. A methodological study of the lipid composition of Acinetobacter calcoaceticus LMD 79-41, Organic Geochemistry 14 (1989), pp. 15-25.

Goossens et al., 1989b H. Goossens, R.R. Duren, J.W. de Leeuw and P.A. Schenck, Lipids and their mode of occurrence in bacteria and sediments - II. Lipids in the sediments of a stratified freshwater lake, Organic Geochemistry 14 (1989), pp. 2741.

Holton and Blecker, 1970 R.W. Holton and H.H. Blecker, Fatty acids of blue-green algae. In: J.E. Zajic, Editor, Properties and Products of Algae, Plenum Press, New York (1970), pp. 115-127.

Huang et al., 1996 Y. Huang, M.Y. Lockheart, G.A. Logan and G. Eglinton, Isotope and molecular evidence for the diverse origins of carboxylic acids in leaf fossils and sediments from Miocene lake Clarkia deposit Idaho USA, Organic Geochemistry 24 (1996), pp. 289-299.

Kolattukudy et al., 1976 P.E. Kolattukudy, R. Croteau and J.S. Buckner, Biochemistry of plant waxes. In: P.E. Kolattukudy, Editor, Chemistry and Biochemistry of Natural Waxes, Elsevier, Amsterdam (1976), pp. 289-347.

Laggoun-Défarge et al., 1999 Laggoun-Défarge, F., Bourdon, S., Chenu, C., Défarge, C., Disnar, J.R., 1999. Etude des transformations morphologiques précoces des tissus végétaux dans la tourbe du marécage de Tritrivakely (Madagascar). Apports des techniques de marquage histochimique en MET et du cryo-MEB haute résolution. In: Elsass, F., Jaunet, A.-M. (Eds.), Structure et Ultrastructure des Sols et des Organismes Vivants. Les Colloques No. 92. INRA, Versailles, pp. 169-182.

Lehtonen and Ketola, $1990 \mathrm{~K}$. Lehtonen and M. Ketola, Occurrence of long-chain acyclic methyl ketones in Sphagnum and Carex peats of different degree of humification, Organic Geochemistry 15 (1990), pp. 275-280. 
Lehtonen and Ketola, $1993 \mathrm{~K}$. Lehtonen and M. Ketola, Solvent-extractable lipids of Sphagnum, Carex, Bryales and Carex-Bryales peats: content and compositional features vs. peat humification, Organic Geochemistry 20 (1993), pp. 363-380.

Leppard et al., 1977 G.G. Leppard, A. Massalski and D.R.S. Lean, Electron-opaque microscopic fibrils in lakes: their demonstration, their biological derivation and their potential significance in the redistribution of cations, Protoplasma 92 (1977), pp. 289309.

Lombardi, 1990 P. Lombardi, A rapid safe and convenient procedure for the preparation and use of diazomethane, Chemical Industry 5 (1990), p. 708.

Matsuda and Koyama, $1977 \mathrm{H}$. Matsuda and T. Koyama, Positional isomer composition of monounsaturated fatty acids from lacustrine sediments, Geochimica et Geochimica Acta 41 (1977), pp. 341-345.

McCarthy and Duthie, 1962 R.A. McCarthy and A.H. Duthie, A rapid quantitative method for the separation of free fatty acids from lipids, Journal of Lipid Research 3 (1962), pp. 117-119.

Mendoza et al., 1987a Y.A. Mendoza, F.O. Gulaçar and A. Buchs, Comparison of extraction techniques for bound carboxylic acids in recent sediments 1 . Unsaturated monocarboxylic acids, Chemical Geology 62 (1987), pp. 307-319.

Mendoza et al., 1987b Y.A. Mendoza, F.O. Gulagar and A. Buchs, Comparison of extraction techniques for bound carboxylic acids in recent sediments 2 . $\beta$ Hydroxyacids, Chemical Geology 62 (1987), pp. 321-330.

Nishimura and Baker, 1987 M. Nishimura and E.W. Baker, Compositional similarities of non-solvent extractable fatty acids from recent marine sediments deposited in different environments, Geochimica et Geochimica Acta 51 (1987), pp. 1165-1178.

Nott et al., 2000 C.J. Nott, S. Xie, L.A. Avsejs, D. Maddy, F.M. Chambers and R.P. Evershed, $n$-Alkane distributions in ombrotrophic mires as indicators of vegetation change related to climate variation, Organic Geochemistry 31 (2000), pp. 231-235.

Pancost et al., 2002 K.D. Pancost, M. Baas, B. van Geel and J.S. Sinninghe Damsté, Biomarkers as proxies for plant inputs to Peats: an example from a sub-boreal embrotrophic bog, Organic Geochemistry 33(2002), pp. 675-690.

Pancost et al., 2003 R.D. Pancost, M. Baas, B. Van Geel and J.S. Sinninghe Damsté, Response of an ombrotrophic bog to a regional climate event revealed by macrofossil, molecular and carbon isotopic data, The Holocene 13 (2003), pp. 921932.

Poupet, 1989 Poupet, P., 1989. Géochimie organique et biogéochimie de sédiments de lagons des atolls de Tikehau et Takapoto (Polynésie francaise). PhD Thesis, Orléans. 
Rietschel et al., 1972 F.T. Rietschel, H. Gottert, O. Lüderitz and O. Westphal, Nature and linkages of the fatty acids present in the lipid-A component of Salmonella lipopolysaccharides, European Journal of Biochemistry 28 (1972), pp. 166-173.

Robinson et al., 1984 N. Robinson, P.A. Cranwell, B.J. Finlay and G. Eglinton, Lipids of aquatic organisms as potential contributors to lacustrine sediments, Organic Geochemistry 6 (1984), pp. 143-152.

Sifeddine et al., 1995 A. Sifeddine, F. Laggoun-Défarge, E. Lallier-Vergés, J.R. Disnar, D. Williamson and F. Gasse, La sédimentation organique lacustre en zone tropicale sud au cours des 36000 dernières années (Lac de Tritrivakely, Madagascar), Comptes Rendus de l'Académie des Sciences (Paris) 321 (1995), pp. 385-391.

Stefanova and Disnar, 2000 M. Stefanova and J.R. Disnar, Composition and early diagenesis of fatty acids in lacustrine sediments, lake Aydat (France), Organic Geochemistry 31 (2000), pp. 41-55.

Volkman et al., 1998 J.K. Volkman, S.M. Barrett, S.I. Blackburn, M.P. Mansour, E.L. Sikes and F. Gélin, Microalgal biomarkers: a review of recent research developments, Organic Geochemistry 29 (1998), pp. 1163-1179.

Volkman et al., 2000 J.K. Volkman, D. Rohjans, J. Rullkötter, B.M. Scholz-Böttcher and G. Liebezeit, Sources and diagenesis of organic matter in tidal flat sediments from the German Wadden Sea, Continental Shelf Research 20 (2000), pp. 11391158.

Xie et al., 2004 S. Xie, C.J. Nott, L.A. Avsejs, D. Maddy, F.M. Chambers and R.P. Evershed, Molecular and isotopic stratigraphy in an ombrotrophic mires for paleoclimate reconstruction, Geochimica et Geochimica Acta 68 (2004), pp. 28492862.

Zegouagh et al., 1996 Y. Zegouagh, S. Derenne, C. Largeau and A. Saliot, Organic matter sources and early diagenetic alternation in Arctic surface sediments (Lena River Delta and Laptev Sea Eastern Siberia) - I. Analysis of the carboxylic acids released via sequential treatments, Organic Geochemistry 24 (1996), pp. 841-857.

Zegouagh et al., 2000 Y. Zegouagh, S. Derenne, C. Largeau and A. Saliot, A geochemical investigation of carboxylic acids released via sequential treatments of two surficial sediments from the Changjiang delta and East China Sea, Organic Geochemistry 31 (2000), pp. 375-388. 